\title{
The Development of an Android-Based Dictionary for Blind
}

\author{
https://doi.org/10.3991/ijim.v14i11.13875
}

\author{
Novi Eka Susilowati ${ }^{(凶)}$, Imam Syafi’i, Aftina, Azzhan Shahrul, \\ Dwi Prasetyo Nogroho, Sekar Bitari \\ Universitas Negeri Malang, Malang, Indonesia \\ novi.eka.fs@um.ac.id
}

\begin{abstract}
This study aims to develop an Android-based Indonesian dictionary for the blind. This study was developed using the Borg \& Gall development model with some adjustments to the needs of this study. The stages of product development are (1) preliminary studies, (2) planning, (3) product development, (4) product validation, (5) first phase revision, (6) trials, (7) second phase revision, and (8) dissemination. The product developed is an android-based dictionary application with voice input and output. This developed product has been validated and tested on a small scale. Validation is carried out for material expert validators, media experts, and practitioners; while small-scale trials were conducted on 5 people with visual impairments. The results of product validation and trial show that the product developed is feasible to be implemented with an average percentage rating of $91.93 \%$. The product developed provides benefits to the blind, which makes it easier to understand the meaning of words in the dictionary and increases the independence of the blind.
\end{abstract}

Keywords - Dictionary, Indonesian language, blind people, android.

\section{Introduction}

The results of the research of several institutions indicate that the level of literacy (one of which includes the ability to read) Indonesia is very low. In fact, the results of the release of the PISA report in 2018 [1] showed that Indonesia ranked 72 out of 77 countries with a successive reading of 371, Mathematics of 379, and Science of 396. Of these three values, reading was a low value, even decreased from 2015.

On the other hand, the ability to literate is very important possessed by an individual, both normal individuals and individuals with special needs (including visually impaired) to be able to survive in the current era of science. In the era of science, goods and services are no longer the main commodities, but science itself is the main commodity. Therefore, if an individual does not have adequate literacy ability, the knowledge provision is also low so that it does not close the possibility that a person cannot compete or survive in the scientific era.

The low ability to titrate is caused by many factors. One of them because of the obstacles in reading. These obstacles can be in the form of difficult words in reading 
that cause someone to be lazy to read. As a result, the ability to titrate is characterized by reading-writing-critical thinking becomes low.

The low literacy ability in Indonesia occurs in almost all groups, including persons with disabilities. This certainly needs serious attention considering the number of people with disabilities in Indonesia is quite high. Based on the National Socio-Economic Survey (Survei Sosial Ekonomi Nasional or SUSENAS) on 2012 [2], the percentage of Indonesian population with disabilities was $2.45 \%$ with details: $39.97 \%$ of people with more than one type of disability, $29.63 \%$ of limitations in seeing, $10.26 \%$ limitations in walking or climbing stairs, $7.87 \%$ limitations in listening, $6.70 \%$ limitations in concentration, $2.83 \%$ limitations in taking care of themselves, and $2.74 \%$ in communication limitations. From this explanation, persons with visual impairments (visually impaired) ranks second most, while at the highest rank is a disability that has more than one type of limitations.

Persons with disabilities have a low level of independence so that there is a sense of dependence on others. That is also why people with disabilities are reluctant to increase their literacy because, for example, to understand the meaning of difficult words in a reading, they must depend on others. This feeling of dependence is certainly disturbing and can reduce the enthusiasm of learning of persons with disabilities.

Based on the facts that have been stated above, a way is needed to increase the independence of persons with disabilities, especially those with visual impairments because the blind is the highest number of persons with disabilities among other people with disabilities in Indonesia. One way that can be used to overcome the low literacy ability of the blind and to increase the independence of the blind is to use a dictionary to understand difficult words or terms. In this way, it is hoped that the blind can have the independence to look up the meaning of words if they have difficulty in understanding the contents of the reading.

According to the Great Dictionary of the Indonesian Language (Kamus Besar Bahasa Indonesia or KBBI), the dictionary is 'a reference that contains words and expressions usually arranged alphabetically along with information about eating, usage, or translation'. The dictionary is a book containing words from a language, usually arranged alphabetically, accompanied by an explanation of its meaning, speech, spelling and so on (American Every Dictionary in [3]). The dictionary is a reference book that contains a list of words or combination of words with information about various aspects of meaning and its use in language, which are usually arranged alphabetically [4]. From these quotations it can be concluded that the dictionary is a reference that contains a list of vocabulary and meanings arranged alphabetically.

On the other hand, the development of communication and information technology (ICT) is developing very rapidly. The development of ICT is marked by the rapid development of the use of mobile phones that have android facilities. This facility is currently used by most Indonesians from various walks of life. No exception for people with disabilities, especially those who are blind. KrJogja [5], one of the electronic newspapers from the Special Region of Yogyakarta, on November 17, 2016 reported that Tio, one of the students of the Faculty of Law, Gadjah Mada University, who is one of the visually impaired, told about the college life of blind people who could not be far from smartphones with the activation of talkback as a helper facility for reading texts 
in a smartphone. For Tio, the talkback facility that is provided in android is very useful for her lectures.

The facts that have been stated are the basis for developing an Android-based Indonesian dictionary for the visually impaired. Because it is intended for the visually impaired, the developed dictionary is equipped with the help of a screen reader or talkback which is one of the features found on Android-based smartphones.

There are similar previous studies. In the 2015, Purnomo [6] research entitled Developing a Visual Studio High School Biology Dictionary Application Based on Plant Classification Subjects in Jepara High School, a high school Biology dictionary was produced by meeting the standards of eligibility criteria for learning media based on media and material aspects. The developed dictionary can also improve student learning outcomes. Another research was conducted by Kurniawan (2006) [7] in the form of a thesis entitled Mobile Braille Touch (MBT): Development of Media Learning Braille Application Based on Android for Blind Person in 2016. The research produced a learning media product that writes Android-based braille letters that have been tested their eligibility and can be published.

This study has similarities and differences with previous studies. When compared with Purnomo's research, this study has something in common that is equally developing products in the form of a dictionary. However, the dictionary developed by Purnomo is a Biology dictionary, while the dictionary developed in this study is an Indonesian dictionary. In addition, the dictionary developed by Purnomo was developed based on visual studio, while the dictionary developed in this study was developed based on Android. When compared with Kurniawan's research, this study has something in common that is equally developing products for Android-based blind people. However, Kurniawan's research was in the form of developing learning media, while this research was in the form of developing an Indonesian dictionary.

\section{$2 \quad$ Method}

\subsection{Product development design}

In this study, the chosen development model is the Borg \& Gall development research model. Borg \& Gall [8] provides ten stages for development research. The research starts from preliminary studies, planning, initial product development, limited trials, first stage revisions, wider trials, second stage revisions, field implementation, final product revisions, and dissemination. However, not all stages of the development of Borg Gall were implemented in this study. This study only uses stages (1) preliminary studies, (2) planning, (3) product development, (4) limited trials (product validation), (5) revision of the first stage, (6) wider trials, (7) second phase revision, and (8) dissemination with details described in Figure 1.

The first stage is a preliminary study. The preliminary study was carried out by gathering information related to dictionary development and visual impairment. This information gathering is done by studying literature from various sources. 


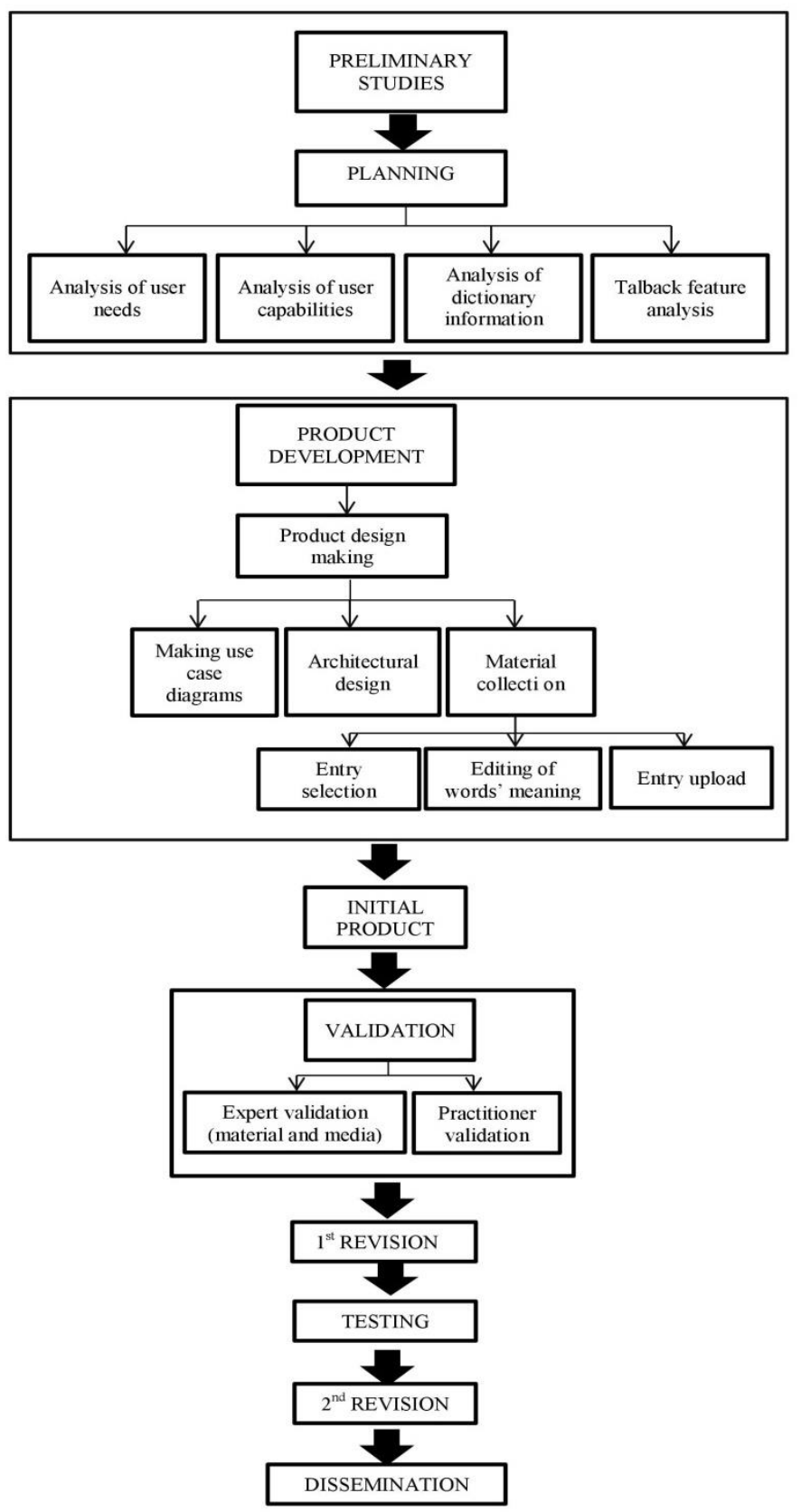

Fig. 1. Research Stage

The second stage taken is product development planning. This stage consists of four sub-phases, namely (a) analysis of the needs of the visually impaired dictionary, (b) 
analysis of the ability to use android by visually impaired, (c) analysis of information about divination, and (d) analysis of the talkback feature. Analysis of the needs of the visually impaired dictionary is used to find information about the need for a dictionary for the visually impaired. Analysis of the ability of blind people to use android is done to find out the capabilities and characteristics of using android by blind people so that an android application can be developed that is in accordance with the capabilities and characteristics of blind people in using android. Analysis of information about the dictionary was carried out to find out the steps in the preparation of the dictionary and other important things related to the preparation of the dictionary. The talkback feature analysis is performed to determine the accuracy of the use of the talkback feature in the application to be developed.

The third stage is product development. At this stage, product development is carried out using the prototyping method. According to Pressman [9], the design of the system to be developed can use the prototyping method. At this stage, initial drafting is also carried out. The prototyping model is a software approach whose purpose is to develop the model into a final system. This stage consists of three sub-phases, namely (a) making use case diagrams, (b) making architectural designs, and (c) collecting materials consisting of selecting entries, improving the meaning of words, and uploading entries to the application database. After this stage is completed, the initial product is obtained.

The fourth step is validation. Validation is carried out to obtain ratings, criticisms, and suggestions from competent parties in their respective fields of product development. Validation is done by expert validation and practitioner validation. Expert validators are divided into two, namely the material validator (lexicographer) and the media validator (information technology expert), while the practitioner validation is carried out by someone experienced in the field of blindness. At the validation stage, a research instrument in the form of a questionnaire containing (a) an assessment of the product in terms of material, media, and users is used as a quantitative data, and (b) criticism and suggestions that support product improvement and is a qualitative assessment. After passing the validation stage, the product is then revised according to the ratings, criticisms, and suggestions from the validators.

The fifth step is to revise the initial product. Revisions are made based on ratings, criticisms, and suggestions given by the validator.

The sixth step is to try out the initial product. Trials were conducted on five people who are blind. A trial was conducted to determine the level of product readiness for use by the visually impaired. Trials were also conducted to obtain input and suggestions from the visually impaired for the product being developed.

The seventh stage is to revise the products that have been tested based on ratings, suggestions, and criticisms from the test subjects. This revision was made to improve the products that have been developed.

The eighth step is to conduct product dissemination. Dissemination is done by publishing the results of product development through scientific publications and publications in the mass media. 


\subsection{Product trial}

The product trial was conducted in Malang City, namely in UPT Binanetra under the auspices of the Social Service of Malang City. This social service specifically houses the blind. The product trial was conducted on 5 blind people who used to use an Android-based gadget with the help of the Google Talkback application.

When testing the product, a mobile phone that has an Android-based Indonesian dictionary application for the blind is provided. Furthermore, the test subjects actually use the dictionary (looking for the meaning of words in the developed dictionary). After that, the test subjects were given a questionnaire containing their ratings, suggestions and criticisms of the product being developed. When conducting a trial, the researcher also observes the degree of independence of the test subject in using the product being developed. Nevertheless, researchers still provide assistance to facilitate the test subjects in operating the developed product.

\subsection{Data analysis}

This research data in the form of quantitative data and qualitative data. Quantitative data were obtained from validator and trial subject evaluations, while qualitative data were obtained from comments, suggestions, and criticisms from validator and trial subjects. Data obtained from experts, practitioners, and development trial subjects are analyzed as a basis for product revisions.

The data in this study were analyzed qualitatively and quantitatively. Qualitative analysis is done to analyze data derived from comments, suggestions, and criticisms from experts, practitioners, and subject matter. The conclusion from the analysis of qualitative data is used as a reference for whether the product needs to be revised or whether the product is feasible to be implemented.

Meanwhile, quantitative analysis was carried out to analyze the data obtained from expert, practitioner and subject assessment. Quantitative data analysis techniques in research and development are in the form of numerical data processing obtained from filling out expert questionnaires, practitioner questionnaires, and questionnaire subject trials. The data has previously been validated by experts and analyzed using the following calculation formula.

Quantitative data processing is done by using the following references.

$$
\mathrm{P}=\frac{\sum x}{\sum x i} x 100 \%
$$

Information:

$\mathrm{P}=$ Percentage

$\sum \mathrm{x}=$ Total number of respondents' answers in all items

$\sum \mathrm{xi}=$ Total ideal score in per item

$100 \%=$ Constant

Furthermore, the percentage of the calculation results is used as a reference for determining product criteria. Determination of product criteria is carried out using the scale as listed in Table 1. 
Table 1. Determination of Product Revision

\begin{tabular}{|l|l|}
\hline \multicolumn{1}{|c|}{ Percentage Interval } & \multicolumn{1}{c|}{ Follow-Up } \\
\hline $90 \%-100 \%$ & Implementation (I) \\
\hline $70 \%-89 \%$ & Implementation with a minor revision (IR) \\
\hline $50 \%-69 \%$ & Revisions according to expert and practitioner notes (R) \\
\hline$<50 \%$ & Revision by modification(U) \\
\hline
\end{tabular}

\section{Result}

The results of the study are described based on the research objectives which include (1) the development of an android-based Indonesian dictionary for the blind, and (2) the validation of an android-based Indonesian dictionary for the blind.

\subsection{Development of an android-based Indonesian dictionary for the blind}

Development process: Making the application design through the stages of making use case diagrams, making architectural designs, and collecting materials. Use case diagrams are made as a guide for the development that will be carried out. Use case in the form of a series of behavioral modeling of information systems created. This stage describes an interaction between one or more actors with the information system created. Use case diagrams are designed for user needs and admin requirements. User needs are designed to make it easier for users to do word searches in a dictionary, view tutorial application usage features, view features about, and view application developer contacts. The admin needs - which in this case is the product developer - are designed to respond to user-assisted features, display contact developers who can be contacted by users, and make updates to the database. Database updating is done to increase the number of entries from various fields.

After the use case diagram phase is made, it continues with the architectural design stage. At this stage the GUI (Graphical User Interface) is designed on the architectural design drawings so that the flow of the application can be seen clearly. At this stage also made a website that is used to store databases online. The online database is used to lighten the capacity of the application so that it is easily installed on low-capacity android phones. In addition, the use of online websites also makes it easier for admins to add entries from various fields. After making an architectural design, material is collected based on the results of the analysis of user needs and abilities, use case diagrams, and making architectural designs.

The process of collecting materials at the design stage of making this application begins with collecting material that will be used as a database. At this stage the first step taken is to document the book that is used as a source of entry. In the initial product development, the book used as a source of entry in the dictionary developed was the entry considered difficult from subject books for high school students. These subjects include (1) chemistry, (2) biology, (3) mathematics, (4) geography, (5) sociology, (6) anthropology, (7) economics, (8) technology, (9) history, and (10) languages. Aside from textbooks, entries are also taken from entries which are considered difficult in the 
newspaper, such as in the newspaper (1) Republika, (2) Jawa Pos, (3) Media Indonesia, and (4) Kompas which is published over a period of two weeks. From these sources, 2,000 basic entries and 12,000 derivatives have been collected.

After the entries are recorded, the entries are given meaning in accordance with the meaning of the KBBI. KBBI which is used as a reference for meaning is the Big Indonesian Dictionary outside the network 1.5.1 and the Big Indonesian Dictionary 5th Edition based on Android. The final stage of material collection is uploading entries to a website created using the PHP programming language, Ajax, and bootstrap as a display. Because entry is done in an online database, adding data can be done in realtime.

Table 2. Minimum Android Specifications for the Indonesian Dictionary for the Blind

\begin{tabular}{|l|l|}
\hline OS & Jelly Bean 4.3 \\
\hline RAM & $512 \mathrm{MB}$ \\
\hline Disk & $10 \mathrm{MB}$ \\
\hline
\end{tabular}

Features in the dictionary: In this developed dictionary, there are five features. These features are (1) home page features, (2) features of about, (3) features of tutorial, (4) main features, and (5) features of contact.

The home page feature contains dictionary names and dictionary icons. On this start page, there is a talkback feature that mentions the name of the developed dictionary application. Feature of About contains an explanation of the dictionary developed. Feature of Tutorial contains an explanation of how to use a dictionary. The main feature contains a page for inputting words to search for their meaning. In this feature, there is a say and listen button. The speak button is located in the lower left corner, while the listen button is in the lower right corner. Both buttons are designed to be large to make it easier for users to click. Feature of Contact contains the name and address of the dictionary developer's correspondence.

The following is a dictionary display developed.

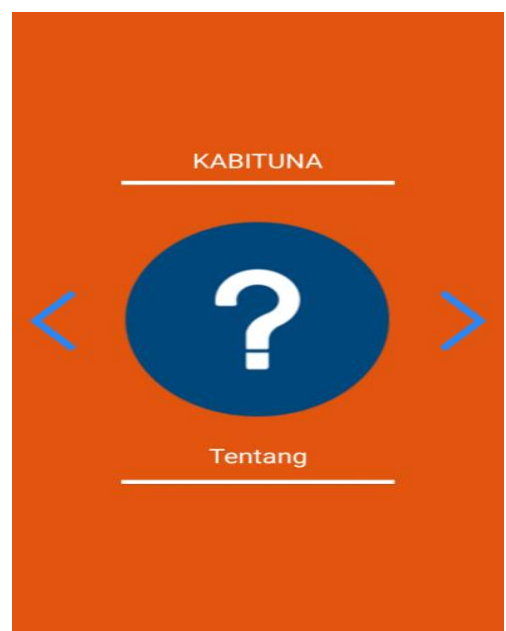

Fig. 2. Home Page Views 


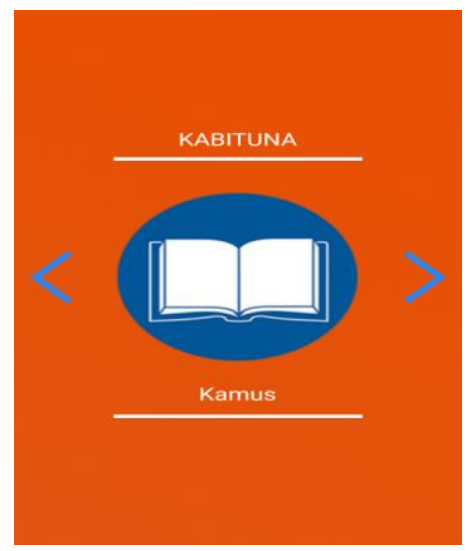

Fig. 3. The Views of About Features

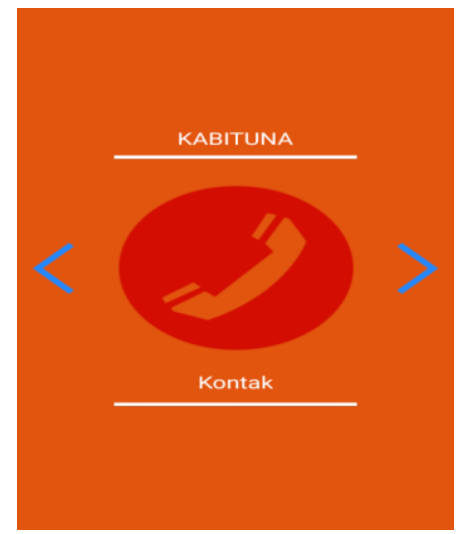

Fig. 4. The Views of Tutorial Features

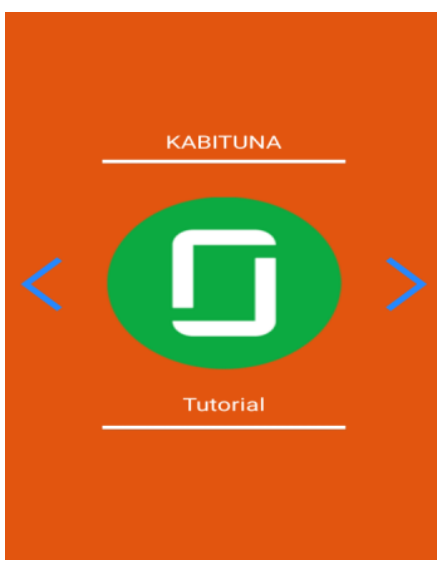

Fig. 5. The Views of Contact Features 

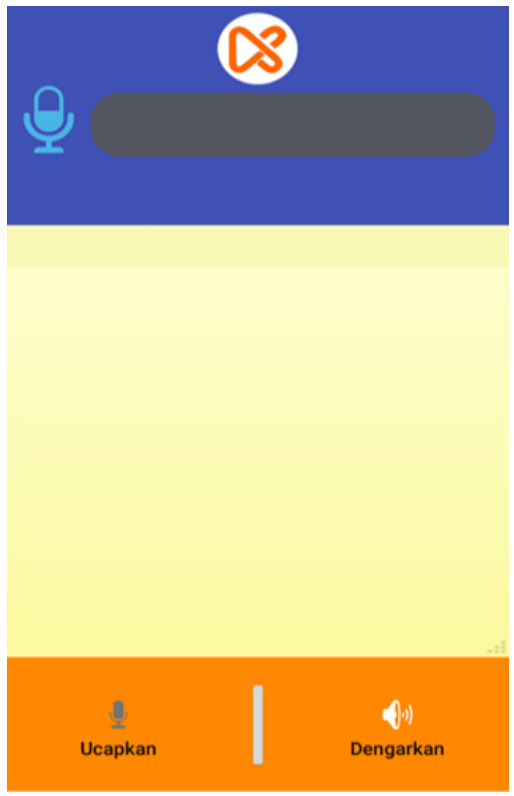
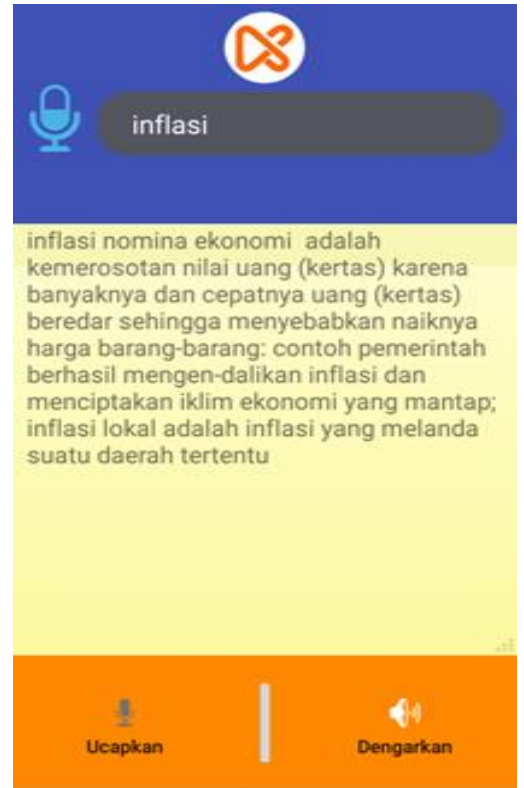

Fig. 6. The Views of The Main Page of The Dictionary

How a dictionary works: In operating this product, to look up the meaning of words, users say words that will be searched for meaning near cell phones that have this application installed. After that, this application will detect the sound and match it with the language data in the database. If the word entered is in the database, the device will provide a response in the form of giving meaning to the word that has been inputted. Giving meaning of words is done through the talkback feature.

When giving a response in the form of giving meaning to a word, the device will repeat the inputted word by repeating the inputed word, give the class the inputed word, add in the entered word science field, add the word adalah (is/are) before giving the meaning of the word, then give the meaning of the word. These things are done to clarify the meaning of words and make it easier for users to understand the meaning of the words entered.

In this developed dictionary, the addition of contoh (example) words is also done before using examples of words in sentences. In addition, the punctuation was also changed such as changing the comma into a semicolon or a dot so that there is a longer gap in the reading of meaning. This was done to give users time to think and concentrate on listening to the meaning that is read by the talkback feature.

The meaning of the dictionary uses many abbreviations, for example $\mathrm{n}$ which stands for noun. Therefore, in this developed dictionary, all the abbreviations contained in the $\mathrm{KBBI}$ are returned to their original form (the form of the abbreviation, not the abbreviation). This is done so that all words can be read correctly by the talkback feature so that it can facilitate the user in understanding the talkback feature. 


\subsection{The validation and trial of android-based Indonesian dictionary for the blind}

The developed product validation dictionary was carried out by three validators consisting of two expert validators and one practitioner validator. Expert validators consist of (1) material expert validators, namely lexicographers, and (2) media expert validators, namely informatics engineers; while the practitioner validator is someone who is an expert in the field of visual impairment. The validation instrument developed was in the form of a questionnaire. The questionnaire compiled contains a number of questions that can be used to measure product viability and contains columns of comments, suggestions and criticisms for product improvement. After the questionnaire is ready, the steps taken are conducting expert validation and practitioner validation.

Material validation was carried out to Indonesian lexicographers. During the material validation process, the validator is given a cellphone that has an android-based Indonesian dictionary application installed for the visually impaired. In addition, the validator was also given a questionnaire containing a list of questions with a total of 15 questions consisting of aspects of the suitability of the material to the needs of the user, the suitability of the contents with Indonesian grammar, the suitability of the language used on the product with the user's linguistic ability, and the suitability of the features to the user's needs. From the questionnaire obtained quantitative data in the form of a value given material validator of $80 \%$ which means the product is feasible to be implemented with a little revision.

Media validation is carried out to informatics engineers. At the time of media validation, there is a mobile phone that has an Indonesian dictionary application installed for the visually impaired for the validator. In addition, the validator was also given a questionnaire containing a list of questions on aspects of the media consisting of 24 questions in which contained an assessment of software engineering, program appearance, and accuracy for the user. The results of the evaluation of the media validator were $95.8 \%$ which means the product was feasible to be implemented.

The validation of the practitioner is carried out to special education experts who also provide education for the visually impaired. During the validation process, there is a mobile phone that has an Indonesian dictionary application installed for the visually impaired for the validator. In addition, the validator was also given a questionnaire that contained a list of questions with a total of 13 questions consisting of aspects of the suitability of the features of the user's ability, suitability of the material to the user's needs, suitability of the language used with the user's ability, and ease of access. From the questionnaire obtained quantitative data in the form of a value given by a practitioner validator of $100 \%$ which means the product is feasible to be implemented.

Based on the three results of validation that have been done, three percentages are generated, comments and suggestions from the validators. The average percentage of eligibility assessment of the three validators is used as a benchmark for product revision. The percentage of eligibility is $91.93 \%$ which means that the product is feasible to be implemented. Then some comments and suggestions given by the validator are also used as a reference to revise and improve the Android-based Indonesian dictionary for the blind in the future. 
In addition to validation, a trial was also conducted on the products developed. The trial was conducted on five people with visual impairments, namely people with low vision and totally blind. The product trial results are presented in the following Table 3.

Table 3. The Result of Product Trial

\begin{tabular}{|c|c|l|}
\hline Trial Subject & Percentage & \multicolumn{1}{c|}{ Information } \\
\hline 1 & $83,3 \%$ & Implementation with a minor revision \\
\hline 2 & $80 \%$ & Implementation with a minor revision \\
\hline 3 & $80,3 \%$ & Implementation with a minor revision \\
\hline 4 & $73,3 \%$ & Implementation with a minor revision \\
\hline 5 & $66,67 \%$ & Revisions according to expert and practitioner notes (R) \\
\hline Mean & $76,7 \%$ & (Implementation with a minor revision) \\
\hline
\end{tabular}

\section{Discussion}

The development of a dictionary for the visually impaired is something important to do since the blind person also sometimes experiences obstacles in understanding the meaning of words which ultimately hinders their understanding of information and communication. The inability of blind people to understand the meaning of words also affects their learning process in school. As a result of not understanding the meaning of the word, blind people also experience difficulties in understanding learning material. In fact, blind people must become unemployed, poor housing, inadequate health care, barriers to lifelong learning, culture, sports and recreation [10].

Because there is no dictionary that can be used by blind people, so far, the blind will ask others if they do not understand the meaning of a word. As a result, the independence of blind people is reduced. In fact, communication and independence are important for blind people as non-disabled people need hearing and vision to communicate [11]. Therefore, blind people also need support in terms of communication, one of which is done by developing a dictionary [12]. In fact, understanding the information that blind people want to know can also influence the decisions they make [13].

One of the ways to improve the independence of blind people is by developing an Android-based dictionary application. Application development is assumed to increase the independence of blind people because by using an Android-based application, anyone can convey the meaning of words openly and directly [14]. In line with this finding, Chomchalerm, et al. [15] states that the development of dictionaries can improve the quality of life of blind people.

People with visual impairments can operate this device independently and they can also understand the meaning of words that they did not previously understand. Thus, blind people are also trained to find the meaning of words independently. This is in line with the findings of Borcaa [16] which states that blind children need to be trained to learn while doing so that their independence can increase. The child should be helped to learn by doing and other sensations as well as learning the sounds. As stated by 
Douglas et al. [17], the main purpose of children with visual impairment learning independence is to train them to develop in life so they can communicate with each other.

The development of dictionaries for the visually impaired is also a form of encouraging the blind to explore the information they get. According to McAllister \& Gray [18], by encouraging children with visual impairments to explore their world, parents and caregivers have done important things to build self-esteem, self-worth and sociability.

This developed dictionary is an application developed based on Android. The selection of Android is based on the fact that currently Android is a platform that is widely used, both by those without special needs and those with special needs. Moreover, Wirawan \& Paryatna [19] also mentioned that the development of an Android-based dictionary needs to be done because students are lazy to open books or print dictionaries.

The choice of this platform is also based on consideration of economic efficiency because Android is an open source platform that requires relatively affordable costs in its development. Moreover, the devices developed for the visually impaired have so far been expensive [20]. In fact, Wirawan \& Paryatna [19] also mentioned that the use of information and communication technology is very likely to be used not only in the classroom, but also wherever and whenever. Even Yumusak, et al. [21] states that the use of information and communication technology in learning can improve the quality and effectiveness of learning.

\section{Conclusion}

Based on the results of research and discussion can be obtained the following conclusions. First, the development of an Android-based Indonesian dictionary for the visually impaired is suitable for use in everyday life. This is known from the results of the validator assessment and trial subjects. Secondly, the development of an Android-based Indonesian dictionary for the visually impaired can improve the independence of visually impaired people in searching for the meaning of words. The effect of this is an improvement in the quality of life for the blind. Third, the selection of the Android platform as the basis for developing dictionaries gives the effect that this dictionary can be used anytime, anywhere, and by anyone. In addition, the use of information and communication technology also increases the effectiveness of searching for the meaning of words by blind people.

\section{Acknowledgement}

We would like to send our gratitude to the research assistant for their great efforts in this project. We also thank the families, students, school staff, and colleagues for their participation and support throughout this study. 


\section{$7 \quad$ References}

[1] PISA. (2019). "Programme for International Student Assesment (PISA) Result from PISA 2018," Online: https://www.oecd.org/pisa/publications/PISA2018_CN_IDN.pdf, PISA. https://doi.org/10.1787/9789264176201-en

[2] Ministry of Health of Republic of Indonesia. (2014). "Buletin Jendela Data dan Informasi Kesehatan: Situasi Penyandang Disabilitas. Semester II.," Jakarta: Kementerian Kesehatan Republik Indonesia.

[3] Chaer, Abdul. (2007). Leksikologi dan Leksikografi Indonesia, Bandung: Rineka Cipta.

[4] Kridalaksana, Harimurti. (2008). Kamus Linguistik, Jakarta: Gramedia Pustaka Utama.

[5] Purwandono, Agung. (2016). "Cara Tio, Mahasiswa Tunanetra Buktikan Kemandiriannya," pp. (Online). https://krjogja.com/ragam/sosok-dan-pemikirannya/cara-tio-mahasiswa-tunanetra-buktikan-kemandiriannya/, 7 November.

[6] Purnomo, Aji. (2015). Pengembangan Aplikasi Kamus Biologi SMA Berbasis Visual Studio dengan Pokok Bahasan Klasifikasi Tumbuhan di SMA Jepara, Semarang: Unpublished thesis. Universitas Negeri Semarang. https://doi.org/10.30821/biolokus.v2i1.444

[7] Kurnawan, Mohammad Rizky. (2016). "Mobile Braille Touch (MBT): Development of Media Learning Braille Application Based Android for Blind Person," Unpulished Thesis. Universitas Negeri Malang, Malang.

[8] Arifin, Zainal. (2011). Penelitian Pendidikan: Metode dan Paradigma Baru, Bandung: Remaja Rosdakarya.

[9] Pressman, Roger. (2012). Rekayasa Perangkat Lunak: Pendekatan Praktis, Yogyakarta: Penerbit Andi.

[10] Panchal, R.A., Papewar, R., Gawli, C., \& Hotchandani, K. (2014). "Interactive Dictionary for Visually Impaired," IOSR Journal of Engineering (IOSRJEN), vol. 04, no. 03 (March. 2014), pp. 42-46. https://doi.org/10.9790/3021-04344246

[11] Hersh, Marion. (2013) "Deafblind People, Communication, Independence, and Isolation," Journal of Deaf Studies and Deaf Education Advance, vol. June 7, no. Online: http://web. eng.gla.ac.uk/assistive/media/publications/communication.pdf. https://doi.org/10.1093/dea fed/ent 022

[12] Sense and Deafblind UK. (1999). "Out of This World, Evidence of The Systematic Exclusion of Deafblind People from Society," A 'Yes to Access' campaign report. Sense and Deafblind UK.

[13] Parker, A. T., Bruce, S. M., Spiers, E., Ressa, S. V., \& Davidson, R. C. (2010). "Deaf-blind Young Adults in Action: Legislative Advocacy and Leadership," Research and Practice in Visual Impairment and Blindness, vol. 3, p. 124-131.

[14] Nyutu, E.N., Cobern, W.W, \& Pleasants, B.A.S. (2019). "Student Engagement Indirect Instruction, Undergraduate Microbiology Laboratories," Journal of Biological Education, vol. 53, no. 3, pp. 250-264. https://doi.org/10.1080/00219266.2018.1469535

[15] Chomchalerm G., Rattanakajornsak, J., Samsrisook, U., Wongsawang, D., \& Kusakunniran, W. (2014). "Braille Dict: Dictionary Application for The Blind on Android Smartphone," in Third ICT International Student Project Conference (ICT-ISPC). https://doi.org/10.1109/ictispc. 2014.6923237

[16] Borcaa, C.V. (2010). "Effective Strategies for Developing Independence in Movement and Travel of Blind Students".

[17] Douglas, G., Pavey, S., McLinden, M., \& McCall, S. (2003). "An Investigation into the Mobility and Independence Needs of Children with Visual Impairment Part 2: The Delivery of the Mobility and Independence Curriculum," The British Journal of Visual Impairment, vol. 21, no. 2, pp. 47-54. https://doi.org/10.1177/026461960302100203 
[18] McAllister, Richard \& Colette, Gray. (2007). "Low Vision: Mobility and Independence Training for The Early Years Child," Early Child Development and Care, vol. November. https://doi.org/10.1080/03004430600594096

[19] Wirawan, I Made Agus \& Paryatna, Ida Bagus Made Ludy. (2018). "The Development of an Android-Based Anggah Ungguhing Balinese Language Dictionary," International Journal of Interactive Mobile Technologies, vol. 12, no. 1, pp. https://online-journals.org/index.php/i-jim/article/view/7105. https://doi.org/10.3991/ijim.v12i1.7105

[20] Yousef, R., Adwan, O., \& Abu-Leil, M. (2013). "An Enhanced Mobile Phone Dialler Application for Blind and Visually Impaired People," International Journal of Engineering and Technology, vol. 2, no. 4, pp. 270-280. https://www.researchgate.net/publication/2588. https://doi.org/10.14419/ijet.v2i4.1101

[21] Yumusak, A., Maras, I., \& Sahin, M. (2015). "Effects of Computer-Assisted Instruction with Conceptual Change Texts on Removing the Misconceptions of Radioactivity," Journal for the Education of Gifted Young Scientists, vol. 3, no. 2, pp. 23-50. https://doi.org/ $\underline{10.17478 / \text { jegys.2015214277 }}$

\section{Authors}

Novi Eka Susilowati, S.Pd., M.Pd. was born in Pasuruan, East Java, Indonesia on August 3, 1987. She is a lecturer of the Indonesian linguistics at Indonesian Department, Faculty of Letters, Universitas Negeri Malang, Indonesia. She graduated with a Bachelor's Degree (S.Pd.) in Indonesian Language and Literature Education, Universitas Negeri Malang, on 2008 and graduated from Postgraduate program of Indonesian Language Education, Universitas Negeri Malang, on 2011.

Imam Syafi'i, S.S. was born in Trenggalek, East Java, Indonesia on June 12, 1996. $\mathrm{He}$ is a student at Postgraduate Program, Indonesian Department, Faculty of Letters, Universitas Negeri Malang, Indonesia. He graduated with a Bachelor's Degree in Indonesian Language and Literature, Universitas Negeri Malang, on 2019.

Aftina, S.S. was born in Lamongan, East Java, Indonesia on April 5, 1996. She is a student at Postgraduate Program, Indonesian Department, Faculty of Letters, Universitas Negeri Malang, Indonesia. She graduated with a Bachelor's Degree in Indonesian Language and Literature, Universitas Negeri Malang, on 2019.

Azzhan Syahrul, S.Pd. was born in Tuban, East Java, Indonesia on Maret 16, 1996. He is a student at Postgraduate Program, Vocational Education, Faculty of Letters, Universitas Negeri Malang, Indonesia. He graduated with a Bachelor's Degree in Informatics Engineering Education, Universitas Negeri Malang, on 2019.

Dwi Prasetyo Nogroho, S.Sn. was born in Tulungagung, East Java, Indonesia on March 2, 1997. He is a student at Art and Design Department, Faculty of Letters, Universitas Negeri Malang, Indonesia.

Sekar Bitari, S.S. was born in Tulungagung, East Java, Indonesia on April 12, 1996. She was a student at Indonesian Department, Faculty of Letters, Universitas Negeri Malang, Indonesia.

Article submitted 2020-02-21. Resubmitted 2020-04-03. Final acceptance 2020-04-05. Final version published as submitted by the authors. 